\title{
THE CELL-CHANGES IN THE HYPOPHYSIS OF THE ALBINO RAT, AFTER CASTRATION
}

\author{
WILLIAM H. F. ADDISON
}

From the Anatomical Laboratory, University of Pennsylvania and The Wistar Institute of Anatomy and Biology

FIVE FIGURES

CONTENTS

Introduction.......................................... 441

Material and methods................................. 442

Normal hypophysis..................................... 443

Experimented hypophysis................................ 448

One month after castration $(69$ days old) $\ldots \ldots \ldots \ldots \ldots \ldots \ldots \ldots \ldots, \ldots \ldots$

Two months after castration (98 days old) ................. 451

Three months after castration (135 days old) ................. 452

Five months after castration (179 days old) ................. 454

Seven months after castration (246 days old) $\ldots \ldots \ldots \ldots \ldots \ldots \ldots, 454$

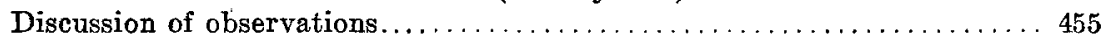

Relation between interstitial cells and hypophysis............... 459

Summary......................................... 459

Literature eited......................................... 460

\section{INTRODUCTION}

The operation of castration in the albino rat is followed by definite progressive alterations in the structure of the ventral glandular portion (pars anterior) of the hypophysis. Indeed, aside from the atrophy of the several related organs of the reproductive system and the diminution of the secondary sexual characters, the cytomorphic changes in this portion of the hypophysis present one of the most striking phenomena resulting from castration. This suggests that perhaps the growth changes, recorded in various organs and tissues after castration, are influenced by this alteration in the structure and physiological activity of the hypophysis. The study of the changes in the hypophysis after castration also affords evidence in regard to 
the debated question of the relation of the several cell-types seen in the ventral glandular portion; i.e., as to whether they are merely functional variations of one type, or really constitute independent types of cells, each forming a different specialized secretion.

The present investigation was begun as a study of the histological details of the interesting observations of Hatai. These were, in part, briefly, that there was a sex-difference in the weights of the hypophyses of male and female albino rats, always in favor of the female (Hatai '13), and that after gonadectomy, there was a decided increase in weight in the male hypophysis, but only a very slight increase in the female hypophysis (Hatai, '15).

It is proposed in the present paper to give a description of the normal male hypophysis of the albino rat, and of the changes consequent upon the removal of the sex-glands. Fichera ('05) was apparently the first to study castration changes, using domestic cattle, domestic fowl and European buffaloes, and his results will be discussed later. No extended study has been made of the albino rat in this respect, although a number of investigators have worked upon other animals, with results somewhat at variance. Reference will be made to these under the heading "Discussion of Observations."

In view of the discordant results, it has seemed advisable to restrict the present phase of the work, to the one form, the albino rat.

\section{MATERIAL AND METHODS}

Both young immature animals and adult animals were used. The operations in the former were performed at about the age of one month, and the experiments were all done by litters, some of the males of the litter being operated upon, and the remainder kept as controls. The hypophysis material from the experimented animals was taken at varying periods after operation, the longest period being nine months. Always the hypophysis from a control animal of the same litter was taken at the same time. In the early part of the work, the weights of the hypo- 
physes were taken as recorded by Hatai ('15). For changes during the first month, material was taken at weekly, or semiweekly intervals. For changes after the first month, material was taken at monthly intervals after operation, up to nine months. Most of the operations were done by Dr. J. M. Stotsenburg of the Wistar Institute, to whom I am greatly indebted.

The fixing fluids which proved most useful were the neutral formol-Zenker mixture of Bensley ('11), and the neutral formolpotassium bichromate fluid as employed in the mitochondrial technique of Cowdry ('16). Others used in the early part of the work were the fluids of Bouin, of Ohlmacher and the aceticosmic-bichromate mixture of Bensley.

After embedding in paraffin, sagittal sections were cut at 3 or 4 microns. For staining were used Mallory's aniline blueorange $G$, iron hematoxylin, and Altmann's acid fuchsin followed by methyl green, as detailed by Bensley and Cowdry.

\section{NORMAL HYPOPHYSIS}

In figure 1 are illustrated the four parts of the rat hypophysis, as seen in median sagittal section. These parts are named, (1) pars nervosa or infundibular portion; (2) pars intermedia, or juxta-neural portion, (3) pars anterior, or ventral glandular portion, and (4) pars tuberalis (Tilney). The pars nervosa is connected with the base of the brain by a stalk which is solid, except at its connection with the diencephalic floor, where it contains a short extension of the third ventricle. The residual pouch of Rathke (5, fig. 1) persists as a cavity between the pars intermedia and pars anterior. Passing cephalad along the hypophyseal stalk is a strand of cells ( 1 to 2 rows deep), constituting the pars tuberalis. Of these several parts of the hypophysis, the ventral glandular portion is the one which shows the most marked changes after castration, and is the only part which calls for detailed description here.

In the normal adult animal, the ventral glandular portion of the hypophysis presents a compact arrangement of masses of cells between the blood-vessels. The distribution of the bloodvessels is best seen in sections parallel to the greatest surface 
expansion of this part of the hypophysis. Beginning cephalad where the largest vessels are seen, these branch and break up into a sinusoidal network, which extends throughout the substance of the gland.

The connective tissue framework is very slight, and there is no definite division into groups of cell masses by connective tissue septa, as is seen in man and many other species.

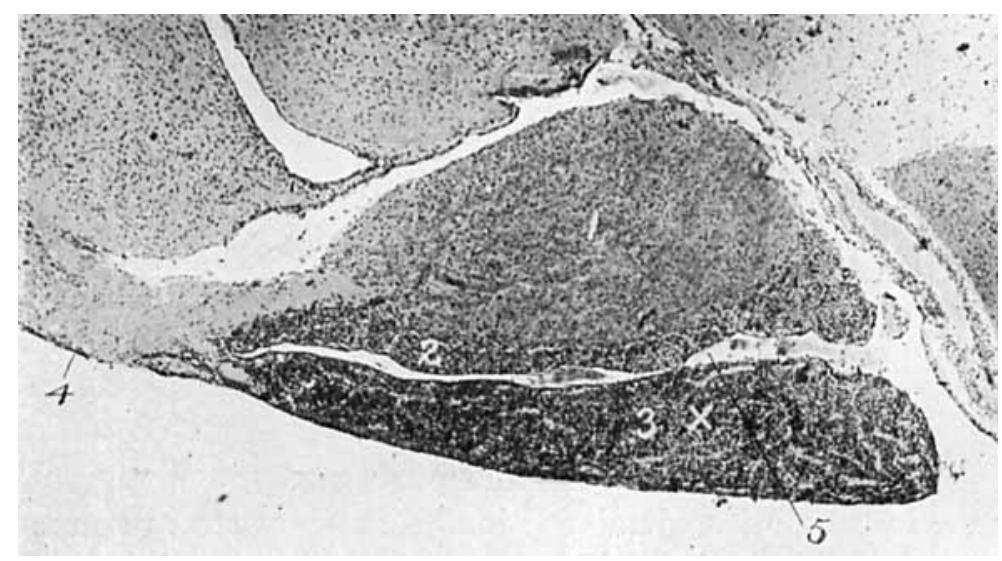

Fig. 1 Median sagittal section of hypophysis of albino rat showing (1) pars nervosa, or infundibular portion; (R) pars intermedia, or juxta-neural portion; (3) pars anterior, or ventral glandular portion; (4) pars tuberalis; (5) lumen of residual pouch of Rathke. $\times 40$.

The differentiation of the cell-types occurs in the first month of post-natal life. At birth nearly all cells are of similar appearance, and still resemble the primitive fetal type. Here and there, examples of two other cell-types may be seen developing from the undifferentiated type. At the end of one month, however, differentiation is well advanced, and the three types are easily recognized. These three types are: (1) acidophiles, so named from containing numerous small closely-packed granules, which stain with acid dyes and especially well with acid fuchsin; (2) basophiles, larger cells than the preceding with cytoplasm moderately basophilic; and (3) unchanged descendants of the primitive fetal type, which may be termed reserve cells. 
In the young mature animal (e.g., 69 days old, figure 2) two of these three types are very distinct, and the third is without such distinct characters. The two distinct glandular types are the acidophiles and the basophiles, and they together form the continuous lines of glandular cells, abutting upon the endothelium of the blood-streams. Away from the sinusoids are located the reserve cells. In the groups of reserve cells between the sinusoids are seen also acidophiles and basophiles, but it would appear that all these latter cells come into close relationship with a bloodvessel, either above or below the plane of section. The reserve cells, however, do not usually form part of the lining glandular cells of the blood-channels in the normal mature hyophysis.

Taking a survey of entire sagittal sections, the acidophiles always outinumber the basophiles, and as a whole occupy a greater proportion of the section, although the basophiles are individually usually larger. The number of the reserve cells varies with the age of the individual, being more numerous in the immature animal, and becoming as a whole less conspicuous in the full-grown. As will be seen later, their number may also vary with the functional conditions of the animal. All types are found intermingled throughout the section in a fairly uniform manner, although sections from different animals may show some definite local variation in the proportionate number of the cells. The most constant variation from the uniform grouping was found in a limited area at the attachedend of the hypophysis, where the basophiles were present to the nearly entire exclusion of the acidophiles and reserve cells. The basophiles of this group become very coarsely granular as age increases. Another variation seen in sections from several different specimens, was a greater proportion of basophiles along the most ventral border of the gland, and a decreased proportion of basophiles in the marginal zone along the caudal half of the pouch of Rathke. In general, in the central part of the caudal half of the sections, the acidophiles were always present in increased proportion to the basophiles. In Mus decumanus, Tilney (11, page 48) found the acidophiles occupying the central regions of this part of the hypophysis. 
The differential staining of the cells to show the three types requires considerable care. With routine stains, the cells do not stain so distinctively as those of man, or of some of the domestic animals. Stendell ('14, p. 116) found that this part of the hypophysis of Mus and Cavia stained less intensely than that of Lepus. Good differential staining of the acidophiles so as to distinguish them from reserve cells is not easily accomplished by eosin. A better method for the acidophilic granules is the acid fuchsin method of Altmann, or as variously slightly modified. With this stain one finds that the granules of all cells are not equally deeply stained, and this is probably due to the cells being in different states of functional activity. The granules are found to be very minute and individual ones are less easily definable than in the human or cat hypophysis. In the Mallory methylene blue-orange $\mathrm{G}$ method, the acidophilic granules are of orange-yellow color and, when the staining is successsful, I think that by this method one can best differentiate the acidophiles from the reserve cells. By this method, too, the cytoplasm of the basophiles is stained blue, thus giving good contrast with the acidophiles. The nuclei are also stained blue but they are usually easily made out. The cytoplasm of the reserve cells is grayish and practically unstained, and the cell boundaries are often indistinct. With this stain at least six weeks old, good preparations are usually obtained after 20 minutes staining. Care must also be taken in differentiating, as there is apt to be considerable variation in the depth of color in different preparations. Wittek ('13) and Trautmann ('09) agree that, while the basophiles are to be found in all the domestic animals, they are as a rule, less distinct than the acidophiles.

While colloid substance is found characteristically in many hypophyses, there is, as a rule, very little if any to be seen in the hypophysis of the normal albino rat. As an exception, it does occur in considerable quantity and then is seen in the residual lumen of the pouch of Rathke, and in small masses in the vascular channels of the ventral glandular portion of the hypophysis but not in the other parts of the hypophysis. 
TABLE I

Average diameters of cells in ventral glandular portion of hypophyses of normal male albino rats at various ages; average of 10 in each case

\begin{tabular}{|c|c|c|c|c|c|c|}
\hline \multirow{2}{*}{$\mathbf{A G E}$} & \multicolumn{2}{|c|}{ ACIDOPHILES } & \multicolumn{3}{|c|}{ BASOPHILES } & \multirow{2}{*}{$\begin{array}{c}\begin{array}{c}\text { RESERVE } \\
\text { GELLS }\end{array} \\
\text { Nuclei }\end{array}$} \\
\hline & Cell bodies & Nuclei & Cell bodies & Nuclei & Maculae & \\
\hline months & $\mu$ & $\mu$ & $\mu$ & $\mu$ & $\mu$ & $\mu$ \\
\hline 2 & $11.5 \times 8.0$ & $6.3 \times 5.2$ & $13.5 \times 11.5$ & $5.8 \times 4.8$ & $5.5 \times 4.0$ & $5.9 \times 4.6$ \\
\hline 3 & $11.1 \times 9.3$ & $6.4 \times 5.3$ & $14.0 \times 11.0$ & $6.7 \times 5.0$ & $5.5 \times 3.8$ & $6.3 \times 4.4$ \\
\hline 4 & $11.3 \times 8.0$ & $6.4 \times 5.5$ & $14.5 \times 11.0$ & $6.7 \times 5.6$ & $6.0 \times 4.3$ & $6.4 \times 5.0$ \\
\hline 6 & $11.4 \times 8.4$ & $6.5 \times 5.1$ & $15.5 \times 11.3$ & $6.8 \times 4.7$ & $5.4 \times 4.3$ & $6.3 \times 4.9$ \\
\hline 8 & $11.2 \times 8.2$ & $6.8 \times 5.8$ & $15.9 \times 12.4$ & $7.1 \times 6.0$ & $5.7 \times 4.5$ & $6.5 \times 5.4$ \\
\hline
\end{tabular}

The size of the two distinct glandular cell types is shown in table 1 and also the size of the reserve cell nuclei. According to the measurements there is continued, though slight, growth of the basophiles throughout the period measured, but there is little change in the acidophiles. In one normal specimen, 136 days old, were found basophiles containing large vacuoles, and consequently of a ring shape. This has also been reported recently by Jackson ('17).

In the glandular cells is seen a cytoplasmic structure, the nature of which is at present under discussion. After the methods of fixation of Bensley and of Cowdry mentioned above in "Material and Methods," it is more evident than after fixing fluids containing acetic acid. I have referred. to it in the description of the figures as the macula. It appears in these preparations

TABLE 2

Average diameters of normal and experimented acidophiles at varying periods after operalion. Normal and experimented animals from same litter at each age. Average of ten measurements in each case

\begin{tabular}{c|c|c|c|c|c}
\hline $\begin{array}{c}\text { TIME } \\
\text { ELAPSED }\end{array}$ & \multicolumn{2}{|c|}{ EXPERIMENTED } & \multicolumn{2}{|c}{ AGE } & \multicolumn{2}{|c}{ NORMAL } \\
\hline $\begin{array}{c}\text { AFTER OP- } \\
\text { ERATION }\end{array}$ & Cell bodies & Nuclei & & Cell bodies & Nuclei \\
\hline months & $\mu$ & $\mu$ & months & $\mu$ & $\mu$ \\
1 & $9.9 \times 7.0$ & $5.6 \times 4.7$ & 2 & $11.5 \times 8.0$ & $6.3 \times 5.2$ \\
2 & $10.7 \times 8.2$ & $5.6 \times 4.9$ & 3 & $11.1 \times 9.3$ & $6.4 \times 5.3$ \\
3 & $10.8 \times 8.1$ & $6.0 \times 5.8$ & 4 & $11.3 \times 8.0$ & $6.4 \times 5.5$ \\
5 & $10.4 \times 7.4$ & $5.4 \times 4.5$ & 6 & $11.4 \times 8.4$ & $6.0 \times 5.1$ \\
7 & $10.7 \times 8.5$ & $6.9 \times 6.2$ & 8 & $11.2 \times 8.2$ & $6.8 \times 5.8$ \\
\hline
\end{tabular}


as a mass, sometimcs rounded, sometimes elongated or irregular, separated by a lighter zone from the surrounding cytoplasm. It is always adjacent to the nucleus, and persists in the experimented hypophyses. After methods of preparation used for demonstrating the Golgi network, it shows, in favorable specimens, as a elose-meshed reticulum. For this reason, I have considered it (Proc. Am. Assoc. Anat., Anat. Rec., January, 1917) to be the structure described as the network apparatus of Golgi. Gemelli ('00) has pictured a larger looser network in the cells of the hypophysis of animals other than rat, using the early method of Golgi for demonstrating this structure. Soyer ('12), however, has found a structure near the nucleus in the glandular cells of the human hypophysis, which he considers merely to be a large centrosphere, and in it he has stained the pair of centrioles. Deineka ('12) has found that in many cases where the position of the centrosphere is known, the position of the net-apparatus agrees with it (cells of Descemet's membrane, leucocytcs, medullary cells of adrenal). Basile ('15) in renal epithelium finds support for the hypothesis of Barinetti, that the reticular apparatus and the centrosomes present a union, anatomical and functional.

In view of these several highly interesting observations, it has seemed best to term the body which one sees in the cells of the hypophysis, macula, until further information is forthcoming. In the basophiles the macula is much larger than in the acidophiles, and by measurement one finds that it increases with the size of the entire cell (table 3 ).

\section{EXPERIMENTED HYPOPHYSIS}

After castration there quickly ensues a reaction, which is discernible in a week, readily apparent in two weeks, and which is progressive throughout the life of the animal. Grossly, there is a color change which is due to the increased amount of blood in the vascular channels, and this hyperaemia no doubt contributes to the increased weight of the organ. Histologically, the first changes are seen in the basophiles, and in the reserve 
TABLE 3

Average diameters of normal and experimented basophiles at varying periods after operation. Normal and experimented animals from same litter at each age.

Average of ten measurements in each case

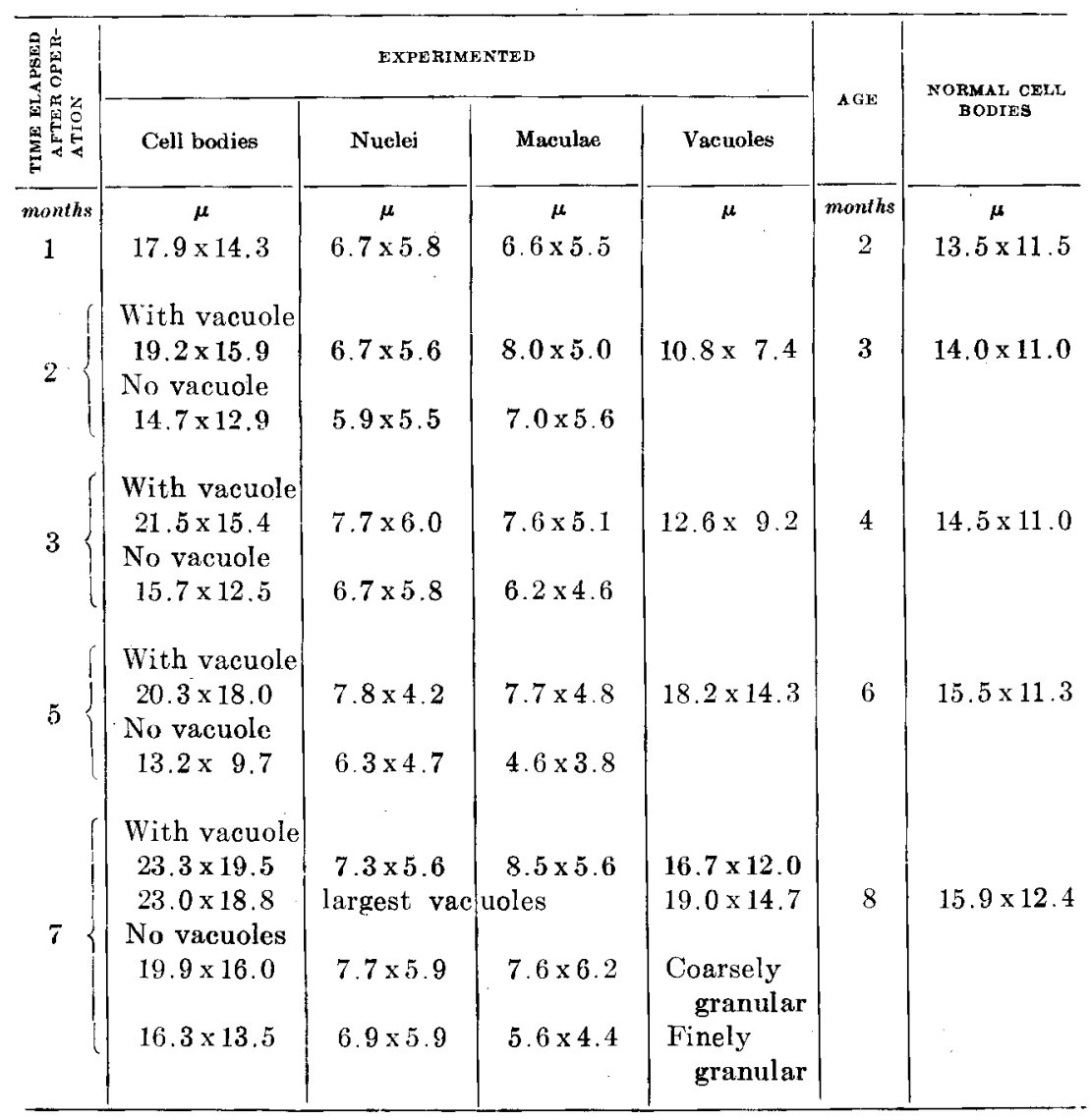

cells. The former increase in size, and some of the latter begin to grow and to take on the staining reaction of the basophiles.

One month after castration (69 days old)

The condition arrived at one month after castration, is shown in figure 3. Comparison with figure 2, taken from the normal control animal of the same litter, shows the striking changes, 
which have been produced due to the experimental procedure. The most evident effect is the increased size of the basophiles; and this, with their greater stainability, makes them much more conspicuous than in the normal sections. The basophiles, however, are not all of the same size, there being many of smaller diameter, and these are probably to be regarded as reserve cells, which have recently differentiated into basophiles. The acidophiles are numerous and very evident, and only slight changes from the normal were noted. The reserve cells show as groups of less conspicuous elements scattered throughout. Other changes, not shown in figure 2 , are the increased diameter of the blood vessels and the constant presence of the colloid-like secretion in the residual pouch of Rathke.

Measurements of the basophiles showed them to average $17.9 \mu \times 14.3 \mu$, in contrast with the normal cells of the same age which measured $13.5 \mu \times 11.5 \mu$, but many individual cells in the experimented hypophysis exceeded this size considerably, and so helped to accentuate the impression of the large size of this type of cell. The nuclei of the cells showed a similar contrast between experimented and normal, measuring in the former, $6.7 \mu \times 5.8 \mu$, and in the latter $5.8 \mu \times 4.8 \mu$. By measurement it was found that the acidophiles were retarded slightly in their growth, averaging $11.5 \mu \times 8.0 \mu$ in the normal, and $10.0 \mu \times 7.7 \mu$ in the experimented. At 45 days of age, the normal acidophiles measure $9.6 \mu \times 7.5 \mu$, so that these experimented animals at 69 days of age, had acidophiles very slightly larger than the normal animal of 45 days.

Measurements of the reserve cells showed that their nuclei increased slightly (from $5.9 \mu \times 4.6 \mu$ normally to $6.1 \mu \times 5.1 \mu$ in the experimented). This probably has little significance, for while it may be due to a real growth of reserve cell nculei, participated in by all, it may be due to the inclusion in the cells measured of one or two cells which are beginning to differentiate and to grow into basophiles. 
Two months after castration (98 days old)

At two months after castration (fig. 4) the differences already noted between normal and experimented hypophysis are increasingly apparent, and these affect all three types of cells. The basophiles are now the most conspicuous elements in the experimented hypophysis and in some of them vacuoles have appeared. These vacuoles are filled with a homogeneous secretion which stains like the colloid in the pouch of Rathke, and probably from these cells come the abundance of colloid, which is now seen in the lumen of the pouch of Rathke. There are two sizes of population recognizable among the basophiles, with, however, many of intermediate size. In general, those which have the vacuoles are the larger, but here and there is seen a cell without a vacuole, as large as those possessing it. The smaller basophiles have usually a more homogeneous cytoplasm and are again regarded as immature basophiles. The cells with vacuoles are still greatly in the minority. Some basophiles are more coarsely granular than others, and this seems to depend upon the age of the cell; i.e., the time which has elapsed since differentiation. Sometimes a cell is seen with many minute vacuoles $(1$ to $2 \mu)$ in one limited area. This probably represents a first stage towards the development of one or more large vacuoles.

Measurements of those with vacuoles show a mean size of $19.2 \mu \times 15.9 \mu$, while those without vacuoles measure $14.7 \mu \times 12.9 \mu$. The larger cells have slightly larger nuclei $6.7 \mu \times 5.6 \mu$ as compared with $5.9 \mu \times 5.5 \mu$ for the smaller. The vacuoles of the largest cells average $10.8 \mu \times 7.4 \mu$.

The acidophiles and the reserve cells of the experimented hypophysis are not so conspicuous as in the normal. Often when measuring acidophiles, there appear to be two sizes of population. Those seen along the margins of blood-streams have more cytoplasm, than those which are found in the cellmasses away from the blood vessels. It seems that this apparent difference may be, however, only a result of the cells having been cut in different planes. Measurements of the acidophiles show them to be not as large, on the average, in the experimented 
hypophysis, as they are in the corresponding positions in the normal. Thus normal acidophiles of this age measured $11.1 \mu \mathrm{x}$ $9.3 \mu$ with nuclei $6.4 \mu \times 5.3 \mu$, while the experimented acidophiles measured $10.7 \mu \times 8.2 \mu$ with nuclei $5.6 \mu \times 4.9 \mu$. There also seems to be a decrease in the staining of the acidophiles, and as they tend to become compressed between the enlarging basophiles, they now play a less conspicuous part in the lining of the blood channels. It should also be mentioned, however, that sometimes in the experimented hypophysis is seen an acidophile quite as large as in the normal hypophysis, and that in such a case, it is usually situated on a blood vessel.

Cell-divisions were found in some sections of both normal and experimented hypophyses of this age.

\section{Three months after castration (135 days old)}

At three months after castration, large basophiles with vacuoles are seen everywhere throughout the sections. One may observe cells showing intermediate stages in the growth of these large vacuolated cells. 1) Some cells contain one or more small vacuoles, their cytoplasm is coarsely granular, and the nucleus is of spherical shape. 2) As the colloid-like material increases, the nucleus becomes more eccentric and the main part of the cell is made up of the colloid-containing vacuole. 3) Finally, the cells become ring-shaped in section, the cytoplasm forming the periphery of the cell, and containing at some point a more or less flattened nucleus. In these cases nearly the entire cell is constituted of the colloid-like material. Although the basophiles possessing vacuoles are more numerous than before, they are still outnumbered by the non-vacuolated basophiles. As in the preceding age, just described, many of the non-vacuolated basophiles are little or no larger than normal basophiles of the control hypophyses. These are probably elements which have differentiated more recently than the large vacuolated cells.

The acidophiles are less conspicuous than in the normal, and this is due partly to their slightly diminished average size and partly to the less intense staining of the acidophilic granules. 
In addition, there may be an actual lessening of the number of stainable granules in some of the cells. Along the blood vessels, the acidophiles usually still occupy more space than the basophiles, although in some localized areas they may be pressed away by the enlarging basophiles. A definite example of this was seen in sections of this age, in an area near the cephalic end, where the basophiles occupied the greatest proportion of the space, but the acidophiles were still there, although rather flattened by the pressure of the neighboring cells. Another exception to the usual cell type mixture, was seen in a limited area towards the caudal end, where there were continuous rows of acidophiles along the blood vessels, but no basophiles. This arrangement of cells was seen at other ages also, in this area. The reserve cell nuclei occur in small groups. These nuclei show a uniform distribution of chromatin, with usualiy a nucleolus. The cytoplasm is pale staining, 'finely granular and has indistinct boundaries.

Measurements of the large vacuoles in the basophiles show them to average $12.6 \times 9.2 \mu$, as contrasted with $10.8 \times 7.4 \mu$ at two months after castration. The large cells containing these vacuoles measure $21.5 \times 15.4 \mu$, with nuclei $7.7 \times 5.9 \mu$. The smaller basophiles without vacuoles measure $15.7 \times 12.5 \mu$, with nuclei $6.7 \times 5.8 \mu$. The normal cells at the same age in the control animals measure $14.5 \times 11.0 \mu$, with nuclei $6.7 \times 5.6 \mu$, which is but slightly less than the small sized basophiles of the experimented hypophyses.

Measurements of the acidophiles do not show any great difference between the preceding age and this one. On the average, the experimented acidophiles measure less than the normal, but occasionally one finds a cell in the experimented hypophysis quite as large as the largest normal acidophile. One gets the impression that the stained acidophile granules are becoming fewer in many cells of the experimented hypophysis, and that these granules are not so closely arranged as in the normal. 
Five months after castration (179 days old)

The vacuoles in the basophiles are still larger than at the three months after castration, and there appear to be more cells with vacuoles than before. However, there are still some of about the normal size and appearance, without vacuoles, which represent cells of younger growth, but doubtless destined to become vacuolated. There is a third variety of a basophilic type, perhaps intermediate between the two preceding varieties, which is nearly as large as many of the vacuolated cells, but is coarsely granular, or perhaps better described as filled with numerous very minute vacuoles. A definite group of these was seen near the cephalic end of the section, and individual ones scattered elsewhere. Along the blood vessels are still both basophiles and acidophiles, the former becoming progressively larger and more conspicuous, the latter becoming less conspicuous. The acidophiles really seem fewer, but this may be due in part to their separation by the large basophiles and also to being compressed by them. Sometimes when situated between several of these large cells they may be pressed into a triangular outline. At other places again, where they are seen to stain distinctly and are not compressed, they appear of about the same size as in the control. The vacuoles in the large basophiles measure $18.2 \times 14.3 \mu$ as contrasted with $12.6 \times 9.2 \mu$ at three months after operation. These cells measure $20.3 \times 18 \mu$ as contrasted with $15.5 \times 11.3 \mu$ in the cells of the normal control animal. Measurement of small non-vacuolated basophiles show them to be $13.2 \mathrm{x}$ $6.7 \mu$, and these must be cells still growing. The acidophiles in the experimented animal measure $10.4 \times 7.4 \mu$ and in the normal animal $11.4 \times 8.4 \mu$, and these measurements are not greatly different from those at the preceding stages.

\section{Seven months after castration ( 246 days old)}

The general appearance of the ventral glandular portion of the experimented hypophysis at this period (fig. 5) is dominated by the large number of vacuolated basophiles, distended with their colloid-like secretion. The presence of these large cells with the groups of smaller cells between gives it an appearance 
which is very different from the more compact and uniform structure of the normal. Measurements of the largest vacuoles average $19 \times 14.7 \mu$, and these are in ring-shaped cells, measuring $23 \times 18.8 \mu$, which is again distinctly larger than at five months after operation. Of the other basophiles without vacuoles, two varieties were seen, some coarsely granular, others finely granular. The former. measure $19.9 \times 16 \mu$, and the latter measure $16.3 \times 13.5 \mu$. In the normal, also, at this age the basophiles were found to be of two varieties, some having finely granular and others coarsely granular cytoplasm. Measurement of these two varieties showed the finely granular here again to be smaller than the coarsely granular (table 3). This suggests that this differentiation of the basophiles may be here an age phenomenon.

In most regions the acidophiles seem distinetly fewer and it appears that many of this type of cell have lost their characteristic staining and now appear more or less like reserve cells.

\section{DISCUSSION OF OBSERVATIONS}

In the albino rat hypophysis, as we have seen, there are three distinct types of cells,-(1) acidophiles, (2) basophiles, and (3) the remaining cells tentatively classed together as reserve cells (chief cells). These last during histogenesis and the early growth of the organ are continually being differentiated into the two functionating types. Small groups of these reserve cells are still present during mature life, and lie dormant until stimulated by the needs of the organism. The removal of the testes we have found to increase the size of the basophiles, and also the number of basophiles, and we believe these new basophiles to come from reserve cells. It is conceivable that, up to a certain time in the life history of these reserve cells, they are all similar and have an equal potentiality for becoming either acidophiles or basophiles. It is possible that this capacity persists after maturity is reached and throughout life, but it may be that at maturity each has acquired a tendency to become definitely of one or of the other type. In our observations, in addition to some reserve cells becoming basophiles, it has ap- 
peared that some acidophiles lose their specifically staining granules and in consequence have the appearance of reserve cells. So that in the later stages after castration, the reserve cells may contain among their number many cells which are dedifferentiated acidophiles.

Fichera ('05), who was the first to study castration changes in the hypophysis, found increased size and weight of the entire organ, and histologically an increase in number and size of eosinophiles (acidophiles). The animals he used in his male series were domestic cattle, European buffaloes and domestic fowl. Wittek ('13) who worked with a large series of individuals "of domestic cattle, agreed in finding that castration increases the weight of the hypophysis. Histologically, however, he differed. He described this part of the hypophysis as composed chiefly of two cell types-eosinophiles (acidophiles) and chief cells (reserve cells). True basophiles were only exceptionally seen. After castration he found no change in cell types and no increase of eosinophiles.

Cimorini ('08) in rabbits and dogs found increase in volume after castration, and an increase in number and size of the eosinophile cells.

Kolde ('12), made observations principally upon the female hypophysis, but as a minor part of his work, also examined three normal male rabbits and one castrated rabbit. He does not indicate any different results in the two sexes, and gives his results as an increase of eosinophiles, and the appearance of special eosinophile cells, the protoplasm of which does not show the usual even stain but is filled with little red granules, perhaps colloid formation.

Marrassini ('10) and Marrassini and Luciani ('11) found no constant histological differences between normal and castrated dogs, sheep, domestic cattle, rabbits and Guinea-pigs. In domestic fowls, however, they found, after complete castration, decided changes. There was more or less increase in weight, but hyperaemia was not constant. In the normal fowl they found a relatively small number of eosinophiles. In the capons the eosinophiles had not changed in number, but in addition 
there was a number of large elements present, containing spherules of varying. size, sometimes larger than the nucleus. The contents of these spaces had a marked electivity for acid colors.

Kon ('08) described a human case. This was of a 32-year old man, examined three years after total castration. He found that the chromophobe cells (reserve cells) had enlarged, so that they had very abundant cytoplasm, and that these cells were present in usually large numbers.

Aside from the inconclusive experiments of Barnabo ('08), the only investigation on albino rats which we have seen reported is that of Zacherl, who worked in Biedl's laboratory.. Biedl ('12) describes his work briefly. He found grossly an increase in volume of the organ, and histologically a diminution in number of acidophiles as contrasted with chief cells. But above all there was a peculiar new cell formation, which he called castration cells. This was an especially large pale cell, with pale stained nucleus, with cytoplasm finely granular and filled with very fine vacuoles. He pictures these at two months after castration, showing the beginning of vacuolization.

Consideration of these observations shows differences which may be attributed to several causes. Where several investigators obtain different results from their studies upon the same form, it is evident that the methods and carefulness of the investigations must have varied. For instance, in domestic cattle, Fichera found relative increase in weight and increase in size and number of eosinophiles; Marrassini found no increase in weight and no constant increase in eosinophiles; while Wittek found increase in weight, but no constant change in the number of eosinophiles. In such a situation, one is apt to be most favorably impressed with the most recent work, as the latest investigator has probably tried to avoid the errors of his predecessors. In domestic fowl, however, Fichera and Marrassini are in practical agreement, finding relative increase in weight and increase in size of one type of cell. They describe this type of cell somewhat differently, but it would seem that the material on which their observations are based must be very similar. 
Most investigators have found hypertrophy of some type of cell. The majority call it eosinophile (acidophile). In the rat, I have considered it the basophilic type and that the new basophiles have come from the reserve cells. Kon, in his human case, thought it was the chief cells (reserve cells) which he saw enlarged, and this seems similar to what I have seen in the rat. Marrassini and Luciani, in the domestic fowl, describe the enlarged cells as having "granular protoplasm, stained fundamentally by hematoxylin and containing a variable number of globules of different sizes, strongly stained by eosin. Between these elements and others of the hypophysis, there are intermediary forms which make one think of the possibility of reciprocal transformation." From this description, it would seem that the castration changes in the domestic fowl may be somewhat similar to those in the albino rat.

Several find droplets of a secretion appearing in the enlarged cells. Thus Kolde in the rabbit, found little red granules which he thought might be colloid formation, and Marrassini and Luciani in the domestic fowl found the enlarged cells containing a varying number of globules. These we have seen in the enlarged cells of the rat hypophysis, and believe the large vacuoles which appear so strikingly in the basophiles to be filled with an accumulation of the same substance. It is a colloid-like secretion, we infer, because of its similarity in appearance to the homogeneous colloid substance which appears in the lumen of the pouch of Rathke at the same time.

Zacherl's results ('12) on the white rat show the same early changes which we have described, although his interpretation is somewhat different. He looks upon the cells which enlarge as a new cell type 'castration cells' and does not attempt to trace their development.

Thus, in the various animals examined, even allowing for the several techniques employed, it would appear that the act of castration does not produce the same reaction in the hypophysis. It is generally believed, however, that the balance of the endocrine glands may be different in different animals, and the results of this form of experiment (removal of one of them) lend support to this view. 


\section{RELATION BETWEEN INTERSTITIAL CELLS AND HYPOPHYSIS}

Since Bouin and Ancel ('03 and later) brought forward strong evidence for the hypothesis that the interstitial cells of the testis represent a gland of internal secretion, it has become the general belief that it is primarily the loss of these cells which gives rise to the castration effects. This is supported by the results of experiments in which the vasa deferentia are tied. This leads to cessation of spermatogenesis, but not destruction of the interstitial cells, and in these animals there are no castration effects. From the point of view of these observations we must regard the loss of the secretion of the interstitial cells by castration, as affecting the balance of the endocrine organs, and in the rat it seems to be chiefly the hypophysis which is stimulated.

\section{SUMMARY}

1. Castration in the male albino rat produces definite histological changes in the structure of the ventral glandular portion of the hypophysis (pars anterior). These include changes in the glandular cells, increase in size of blood channels and marked production of colloid.

2 . The cells of this portion of the hypophysis are, in the classification here used, acidophiles, basophiles and reserve cells. After castration the basophiles increase in size and number. The largest ones begin to become vacuolated at two months after operation. During succeeding months the number of vacuolated cells increases; the largest ones become ring-shaped, with cytoplasm and nucleus at the periphery, and the central part made up of the colloid-containing vacuole. The acidophiles are not much affected at first, except for a slight diminution in average diameter. Gradually some of them show diminished number of granules and lessened stainability. At seven months after castration the number of distinctively stained acidophiles is decidedly reduced (fig. 5). Some of the reserve cells in the first months after castration appear to become basophile cells. In the later months some of the acidophiles appear to gradually dedifferentiate into reserve cells. 
3. The basophiles, after certain fixations, show a large cytoplasmic body (macula), which may be the reticular apparatus of Golgi, or centrosphere, or both combined. The acidophiles show a similar structure, much smaller in size.

4. The experiments afford strong evidence for the view that there are at least two actively functionating types of cells in this part of the hypophysis and that both of these are derived in histogenesis from a less differentiated form (reserve cells). Some of the latter persist during mature life, and serve as the source of supply for the other two types.

In conclusion, I wish to thank Professor Piersol for advice and criticism, and Professor Donaldson, of The Wistar Institute, for constant interest in the study. I also wish to acknowledge the kind assistance of Mr. E. F. Faber, instructor in art in the School of Medicine, in the preparation of the drawings.

\section{LITERATURE CITED}

BARnABo 1908 Sui rapporti tra la glandola interstiziale del testicolo e le glandole a secrezione interna. Policlinico, vol. 15, pp. 134-144.

Basile, G. 1915 Sulle modificazioni dell'apparato reticolare interno di Golgi nell 'epitelio renale di animali nefrectomizzati. Intern. Monatsch. für Anat. u. Phys., Bd. 31, pp. 1-5.

Benstey, R. R. 1911 Studies in the pancreas of the guinea-pig. Am. Jour. Anat., vol. 12, pp. 297-388.

Biedr, A. 1912 Innere Sekretion, Berlin, vol. 2, p. 107 et seq.

Crmorini, A. 1908 Sur l'hypertrophie de l'hypophyse ećrébrale chez les animaux thyréoidectomisés. Arch. Ital. Biol., vol. 48, pp. 387-400.

CowDry, E. V. 1916 The structure of chromophile cells of the nervous system. Publ. 224 of the Carnegie Institution of Washington. Contribution to Embryology, No. 11, pp. 27-43.

DeINeKa 1912 Der Netzapparat von Golgi in einigen Epithel- und Bindegewebszellen während der Ruhe, und während der Teilung der selben. Anat. Anz., Bd. 41, pp. 289-309.

Fichera, 1905 Sulla ipertrofia della ghiandola pituitaria consecutiva alla castrazione. Il Policlinico, vol. 12.

1905 Sur l'hypertrophie de la glande pituitaire consécutive a la castration. Arch. Ital. Biol, vol. 43.

Gemelim, E. 1900 Contributo alla conoscenza sulla struttura della ghiandola pituitaria nei mammiferi. Boll. Soc. Med. Chir., Pavia, pp. 231-242.

Hatar, S. 1913 The effect of castration, spaying or semi-spaying on the weight of the central nervous system and of the hypophysis of the albino rat. Jour. Exp. Zool., vol. 15, pp. 297-314. 
HatAI, S. 1915 The growth of organs in the albino rat as affected by gonadectomy. Jour. Exp. Zool., vol. 18, pp. 1-67.

JACKsoN, C. M. 1917 Effects of inanition and refeeding upon the growth and structure of the hypophysis in the albino rat. Am. Jour: Anat., vol. 21, pp. 321-358.

KoLDE, W. 1912 Untersuchungen von Hypophysen bei Schwangersehaft und nach Kastration. Arch. f. Gynäkologie, Bd. 98, pp. 505-524.

Kon, J. 1908 Hypophystudien. II. Ueber das Verhalten der Hypophyse nach Kastration. Ziegler's Beiträge zur pathol. Anat. und zur Allgem. Path., Bd. 44, pp. 266-271.

Marrassini, A. 1910 Sur les modifications que la castration peut déterminer dans les organes glandulaires de quelque animaux, et spécialment sur celles que l'on rencontre dans l'hypophyse. Arch. Ital. Biol., tome 53 , pp. $419-431$.

Marrassini, A., and Luciani, L. 1911 Effets de la castration sur l'hypophyse et sur d'autres organes glandulaires. Arch. Ital. Biol., tome 56, pp. 395-432.

SoYer, C. 1912 Etudes sur l'hypophyse. Arch. d'Anat. micr., vol. 14, pp. $145-308$.

Stendeli, W. 1914 Die Hypophysis Cerebri (part VIII, of Oppel's Lehrbuch der vergl. mikr. Anatomie).

TILNey, F. 1911 Contribution to the study of the hypophysis cerebri. Memoirs of The Wistar Institute of Anatomy and Biology, no. 2.

WiтTER, J. 1913 Ueber das Verhalten der Rinderhypophyse bei den verschiedenen Geschlechtern in der Gravidität und nach der Kastration. Arch. f. Anat. u. Phys; Anat. Abth. ; Suppl. Band, pp. 127-152.

ZACHERL, 1912 In Biedl's Innere Sekretion. vol. 2, p. 107 et seq. 
PLATE 1.

EXPLANATION OF FIGURES

\section{ABBREVIATIONS}

$a$, acidophile cells

$c$, reserve cells

$b$, basophile cells

$m$, macula

$b^{\prime}$, basophile cells with vacuoles

$n$, nucleus

Ventral glandular portion of hypophyses of male albino rats, normal and experimented. All drawings made from the region (x) indicated in figure 1, p. 444 . Figures 2 and 3 were made from preparations fixed in neutral formol-Zenker and stained with Mallory's aniline blue-orange G. Figures 4 and 5 were made from preparations fixed in neutral formol-potassium bichromate, and stained with Mallory's aniline blue-orange $G$. Outlines were drawn with the aid of a camera lucida, using Spencer apochromat lens, $1.5 \mathrm{~mm}$. and Spencer compensating ocular, No. 5. The drawings were made at a magnification of 700 diameters and reduced in reproduction to 600 diameters.

2. Normal hypophysis of male albino rat, two months old.

3. Hypophysis of rat of same age as in figure 2, one month after castration.

4. Hypophysis of rat, three months old, two months after castration.

5. Hypophysis of rat, eight months old, seven months after castration. 


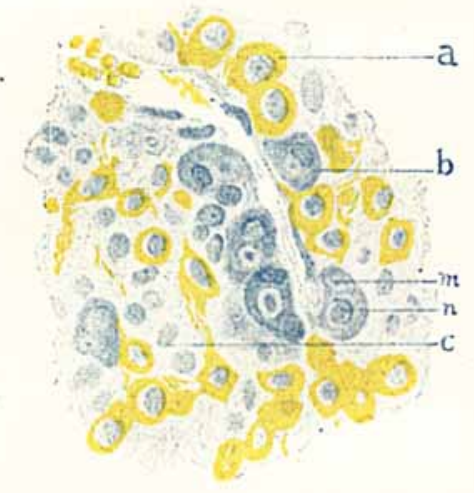

2

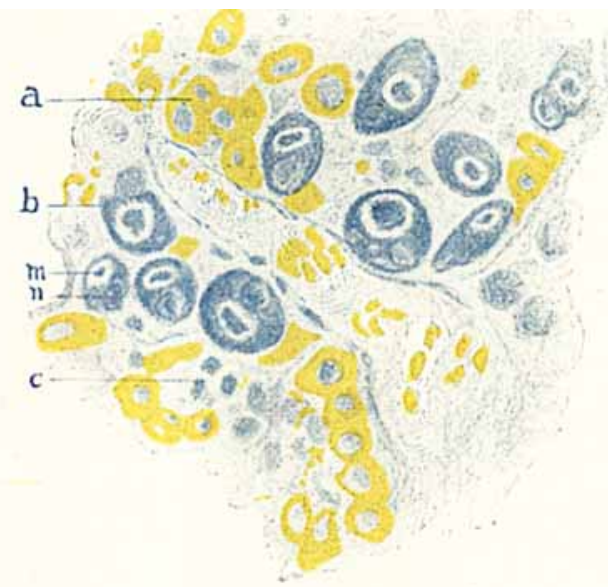

3

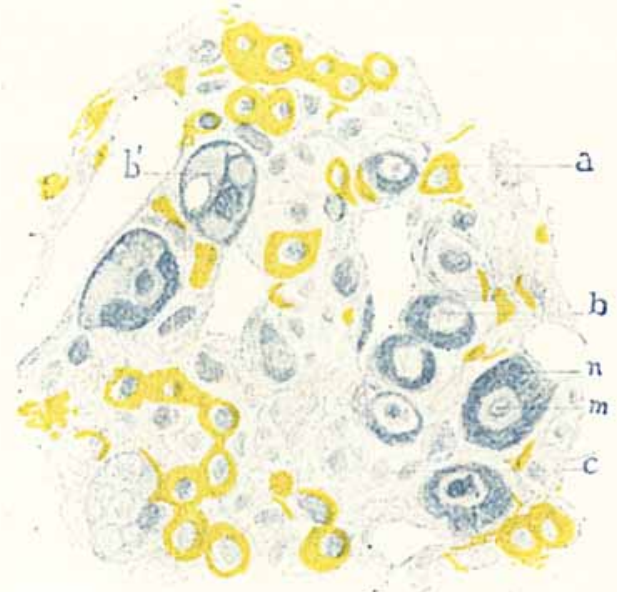

4

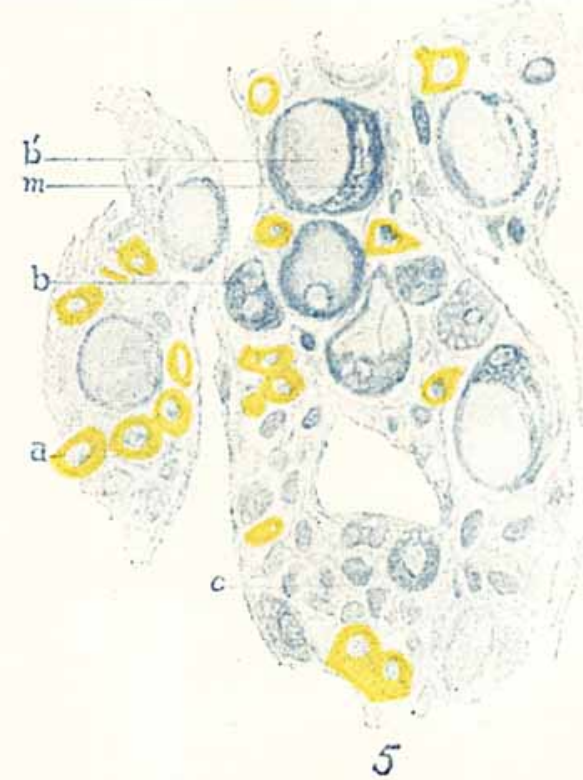

463 